\title{
The Influences of transglutaminase enzyme dosage on the meat characteristic from restructuring the animal and vegetable protein sources
}

\author{
Setiadi $^{1, *}$, Wawan Irawah Sah ${ }^{1}$, and Nadia Alisha ${ }^{1}$ \\ ${ }^{1}$ Bioprocess Engineering Study Program, Departement of Chemical Engineering, Faculty of Engineering Universitas \\ Indonesia, Depok 16424, Indonesia.
}

\begin{abstract}
Transglutaminase (EC 2.3.2.13) catalyses an acyl-transfer reaction in which the $\gamma$-carboxamide group of peptide-bound glutaminyl residues are the acyl donors. In this research is compare the influence of transglutaminase enzyme dosage on the animal protein which is duck meat and vegetable protein which is analog meat from TSP and soy powder. The sample was tested by some instrument analysis namely $\mathrm{pH}$ meter, Texture Profile Analyzer (TPA). Then, the sample was analized its nutrition by Proximate test. By these tests, it could be obtained the optimum of amount transgluminase dosage in animal or vegetable protein source. The experimental variations is the enzyme dosage. The enzyme dosage for animal protein source are $0.0 \% ; 0.3 \% ; 0.6 \%$ and $1 \%$, while vegetable protein source are $0.0 \% ; 0.5 \% ; 1,0 \% ; 1.5 \%$ and $2 \%$ with the duration of $24 \mathrm{~h}$ incubation in $4^{\circ} \mathrm{C}$. The result showed that the characteristic of each sample observed, increased dosage of transglutaminase enzyme affects the texture of sample as evedenced by TPA. In animal protein the optimum enzyme used is $0,6 \%$, while in vegetable protein the optimum enzyme is $1,5 \%$ as evedenced by TPA and acidity test level.
\end{abstract}

\section{Introduction}

Proteins are the macronutrients the body needs in large quantities. Protein is a source of amino acids containing elements $\mathrm{C}, \mathrm{H}, \mathrm{O}$, and $\mathrm{N}[10]$. Proteins are derived from animal protein and vegetable proteins. Protein serves as a builder, growth and maintenance of tissue and replaces the cells that has died. If the protein deficiency, the body will lose weight, the immune system weakened and can cause malnutrition.

The transglutaminase enyme could be isolated from genus Streptoverticillium or Streptomyces. Commonly, the enzyme called microbial transglutaminase or MTGase [9]. Transglutaminase (TGA-ase, EC 2.3.2.13) is an enzyme that catalyzes the formation of crosslinks between protein molecules (the formation of polymers between protein molecules) [7] as seen in Fig.1.

This enzyme catalysis polymerization and forms crosslinking $\varepsilon$-( $\gamma$-glutamyl) lysine between glutamine (Gln) and lysine (Lys) residues [9]. The reaction also produces a molecule of amonia $\left(\mathrm{NH}_{3}\right)$.Transglutaminase has an optimum $\mathrm{pH}$ around 5-8. However at $\mathrm{pH} 4$ or 9, the transglutaminase enzyme still express enzymatic activity. The optimum temperature for enzymatic activity is $50-55^{\circ} \mathrm{C}$ and can perform fully sustained enzymatic activity even at $50^{\circ} \mathrm{C}$ for 10 minutes. The transglutaminase enzyme loses its enzymatic activity within a few minutes on heating to $70^{\circ} \mathrm{C}$. Transglutaminase still expressed enzymatic activity at $10^{\circ} \mathrm{C}$, and still retained some activity at temperatures just above the freezing-point [9].

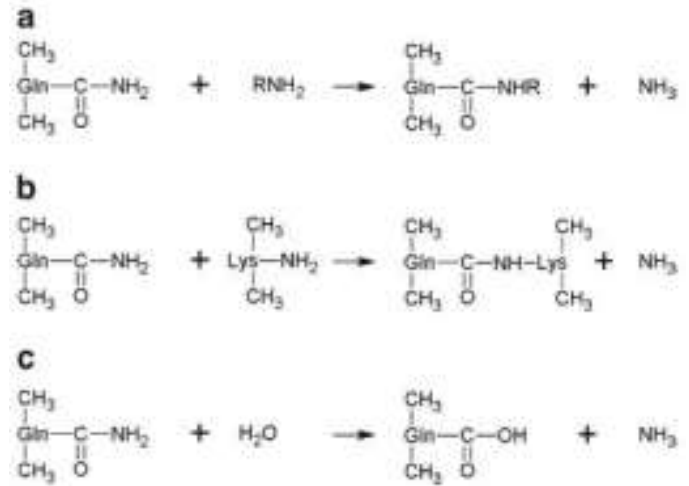

Fig. 1. The reaction catalyzed by transglutaminase included (a) acyl transferation; (b) cross-linking between Gln and Lys residues of protein pr petides; (c)deamidation.Source: Kieliszek \& Misiewicz (2014)

Application of transglutaminase enzyme is very popular in food industry. The enzyme can affect various food characteristics, such as texture, solubility, viscousity, gelation capacity and water retention capacity. In commercial food processing, transglutaminase is used to bond proteins together. The enzyme as an agent to improcve the texture protein-rich foods.

This study was utilize the source of proteins by animal and vegetable. The use of these protein sources to compare the enzyme transglutaminase reactions in animal and vegetable proteins. The source of animal protein used is duck meat. Duck meat used is an

\footnotetext{
*Corresponding author: setiadi.eng@che.ui.ac.id
} 
unproductive laying duck meat (afkir) which has a low quality such as smelling fishy, coarse texture and hard. The meat needs to be restructured using transglutaminase enzymes to make the better texture. Meanwhile, the source of vegetable protein used is a source of soy protein from a mixture of soybean flour and TSP then restructured using transglutaminase enzymes to become analog meat. The use of the material is due to produce analog meat that has high protein and good texture quality.

In this experiment was compared through $\mathrm{pH}$ testing, texture profiles, and proximate analyzes. The $\mathrm{pH}$ test is performed to see the acidity level of the animal and vegetable protein samples. A texture profile profile using a TPA (Texture Profile Analyzer) is performed to determine the transglutaminase enzyme in animal and vegetable protein samples through characteristic texture parameters such as hardness, elasticity, and cohesiveness. Proximate analysis was performed with the aim of obtaining nutritional standard values of food such as protein content, fat content, carbohydrate levels, and water content. This analysis to determine whether the occurrence of changes in nutritional content of animal and vegetable protein sources when treated with transglutaminase enzyme. In this study also aims to determine the optimum levels of transglutaminase enzymes that are added to obtain a good texture value on the source of animal protein and vegetable.

\section{Methods}

\subsection{Materials}

The materials used in this research are duck as an animal protein source, a mixture of soy powder and Texturized Soy Protein (TSP) as a vegetable protein source, tranglutaminase enzyme (MTG), water and alcohol.

\subsection{Preparation Tools and Materials}

To prepare the necessary tools in the experiment involves the provision of materials and tools, first sterilization of tools used such as sclaes and gloves with alcohol. The transglutaminase enzyme is obtained from a manufacturer of Activa ${ }^{\circledR}$ TG-BW-MH Ajinomoto.

\subsection{Preparation of Proteins Source and Enzyme}

\subsubsection{Animal Protein Source}

After preparing the required tools and ensuring the availability of the ingredients, duck meat is cleaned by cutting the meat carefully off the bones and unused body parts such as head before washing. There are two types of treatment for duck meat based on their use for different analysis test. (I) grind the duck meat and then shape into cylinder with diameter of about $2 \mathrm{~cm}$ and high $3 \mathrm{~cm}$ for texture profile sample after mix with enzyme, and (II) pure the duck meat and separate into 100 grams each as the sample unit. The dosage of enzyme was used is $0.0 \% ; 0.3 \% ; 0.6 \%$ and $1 \%$.

\subsubsection{Vegetable Protein Source}

First, pour the water over the TSP, then cover with plastic wrap that creates an airtight seal and let it until the water has been absorbed. After that, mix TSP with $25 \%$ Soy Powder of TSP weight. TSP is used as a chewy material for meat analog, while soybean flour is the most enzyme-bound ingredient. The dosage of enzyme was used is $0,5 \% ; 1 \% ; 1,5 \%$, and $2 \%$.

\subsection{Proteins Processing with Enzyme}

The enzyme with adjusted dosage is mixed evenly through mixing of each protein source. After that, wrap the samples up with plastic wrap until it is airtight and covered all the parts perfectly. All samples then are labeled before being stored and incubated for $24 \mathrm{~h}$ in a chiller $\left(4^{\circ} \mathrm{C}\right)$ with an adjusted duration. Specifically, for the texture profile test, samples were made for seven duplicates.

\subsection{Test and Product Analysis}

The tests are Acidity Test Level $(\mathrm{pH})$, Texture Test with Texture Profile Analyzer TA-XT2i type and Proximate Test.

\section{Result and Discussion}

\subsection{Acidity Test Level (pH)}

The $\mathrm{pH}$ test was conducted to determine the presence of ammonia $\left(\mathrm{NH}_{3}\right)$ as a result of the enzymatic reaction. The reaction can be seen in the figure 1 that the reaction of catalyzed by transglutaminase enzyme is produce the ammonia $\left(\mathrm{NH}_{3}\right)$. So, if the $\mathrm{pH}$ value is increase, then most likely it is because of the ammonia content of the enzymatic reaction. The optimum $\mathrm{pH}$ of $\mathrm{MTG}$ was ranged around 5 to 8 , but will still expresses enzymatic activity at $\mathrm{pH} 4$ or 9 [8].

Before the sample is tested, the sample is dissolved first with aquades and homogenized using a magnetic stirrer. Solid sample weight 3.5 grams dissolved with 15 $\mathrm{ml}$ of aquades.

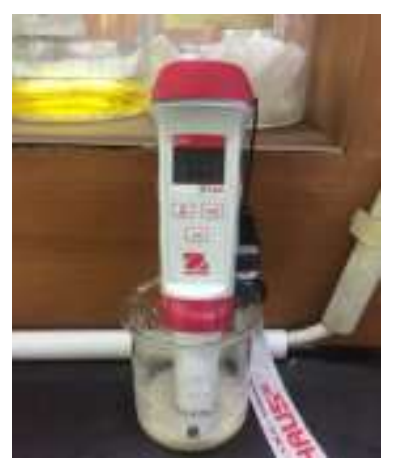

Fig. 2. Acidity Level Test with $\mathrm{pH}$ meter 


\subsubsection{Animal Protein}

Washing can affect the degree of acidity of meat duck. The washing stage is done for removing the natural components of duck, such as water-soluble proteins, blood and other components, which can affect the decay processes (lipid oxidation and microorganisms) during the storage process at low temperatures [15]. After being incubated and given time to react in a period of time, here is a description of the sample change on samples, as shown on Figure 3.

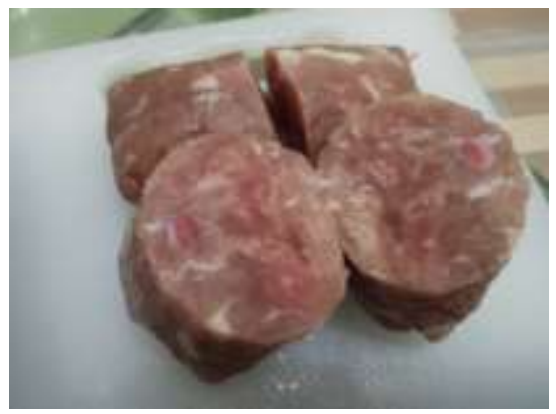

Fig. 3. The typical result of meat restructuring based on animal protein sample

The result of $\mathrm{pH}$ values are shown in Tabel 1 below

Tabel 1. Result of $\mathrm{pH}$ test on animal protein

\begin{tabular}{|c|c|}
\hline Enzyme Dosage & $\mathbf{4}^{\circ} \mathbf{C}$ \\
\hline $0 \%$ & 6.25 \\
\hline $0,3 \%$ & 6.41 \\
\hline $0,6 \%$ & 6.43 \\
\hline $1 \%$ & 6.45 \\
\hline
\end{tabular}

In the Table 1 above shows that duck meat with different levels of dosage of transglutaminase enzyme not very significant difference to the $\mathrm{pH}$ of meat. The degree of acidity $(\mathrm{pH})$ of duck meat in this study is still within the normal range in 5.4 to 7.0. According to Jiang $\&$ Yin (2001) [8], the transglutaminase enzyme has an optimum $\mathrm{pH}$ ranging from 5-8, but still shows enzymatic activity at $\mathrm{pH} 4$ or 9 . Thus from all data indicates that the performance of this enzyme reaches optimum under study conditions. In the results of $\mathrm{pH}$ data above if viewed from the dosage of enzymes, the higher the dosage the higher the $\mathrm{pH}$ produced. The increased value of acidity $(\mathrm{pH})$ as the addition of transglutaminase enzyme shows the result of crosslinking reaction to the sample protein, which chemically produces the ammonia base molecule $\left(\mathrm{NH}_{3}\right)$ as shown in Fig. 1, thus the more alkaline ammonia content is able to influence the $\mathrm{pH}$ value.

\subsubsection{Vegetable Protein}

The using vegetable protein from soybean was intended to compare the result of restructuring the meat animal as protein source. The contain of protein in vegetable source is supposed to be lower concentration than that of the animal. Based on the theoretically, the reaction should be occurred because the characteristic of transglutaminase enzyme only catalyze the protein molecules without the protein source.

The restructuring based on the vegetable protein with using soy source, after the transglutaminase enzyme addition and then incubated in the $24 \mathrm{~h}$ to proceed the crosslinking reaction, the typical result of the sample is shown in Figure 4.

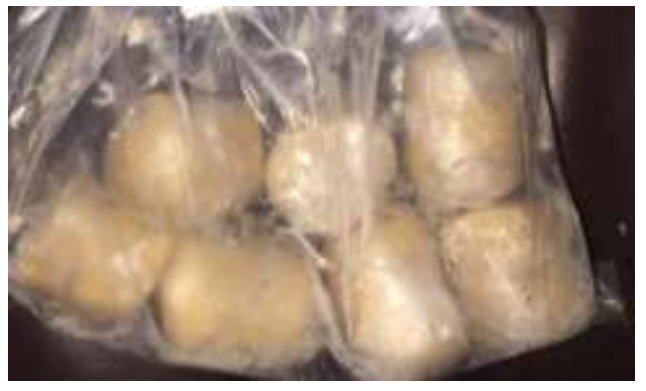

Fig. 4. The typical result of restructuring based on vegetable protein sample

The control sample was the sample with the dosage of transglutaminase enzyme $0 \%$. And the results of $\mathrm{pH}$ measurements has been performed as seen in Table 2 .

Tabel 2. Result of $\mathrm{pH}$ test on vegetable protein

\begin{tabular}{|c|c|}
\hline Enzyme Dosage & $\mathbf{4}^{\circ} \mathbf{C}$ \\
\hline $0 \%$ & 6,50 \\
\hline $0,5 \%$ & 6.65 \\
\hline $1 \%$ & 6.68 \\
\hline $1,5 \%$ & 6.69 \\
\hline $2 \%$ & 6.70 \\
\hline
\end{tabular}

The Tabel 2 above shows that overall $\mathrm{pH}$ value are higher with the addition of transglutaminase enzyme than sample control. Thus, the data of this vegetable protein source show that the performance of this enzyme reaches optimum under this study conditions. Dosage of transglutaminase enzyme $0,5 \%$ to $2 \%$ caused the $\mathrm{pH}$ level (more alkaline) increase, but its more contant at dosage of enzyme $1,5 \%$ for vegetable protein. The increased $\mathrm{pH}$ value as the transglutaminase enzyme addition shows the results of crosslinking reactions in sample proteins, which chemically produce ammonia molecules.

\subsection{Texture Profile Analyzer}

The purpose of Texture Profile Analyzer) using Texture Profile Analyzer (TA-XT2i) is to find out the characterics of animal and vegetable protein texture that have been modified with MTG. The measurement conditions have also been adjust to a certain research reference [1]. The parameters are hardness, cohesiveness and springness. Hardness is the maximum force required to suppress the sample [2] and its units is Newton (N) or gram-force (gf). can be defined as how far a sample can undergo deformation before dehiscent and cohesiveness has no dimension number used. Springness has the goal 
of of determining a sample's ability to return to its original state after first pressure [2]. The unit of springness is percentage $(\%)$. The sample used in this experiment, for animal protein is with dosage of enzyme $0 \%$ as a control, $0,3 \%, 0,6 \%$ and $1 \%$, whereas vegetable protein is with dosage of enzyme $0 \%$ as a control, $0,5 \%$, $1 \%, 1,5 \%$ and $2 \%$.

\subsubsection{Animal Protein}

Texture profile analysis was done on duck products, both with or without MTG enzyme which used as control addition. The test was carried out at room temperature or about $20-22^{\circ} \mathrm{C}[10,11]$. The result of Texture Profile Analyzer in animal protein can be seen on tabel below. The results in Table 3 show that the addition of transglutaminase enzyme increases the change in hardness, cohesiveness and elasticity of a sample in which this result is in line to the result of research obtained by Kang et al. (2017). The increase in dosage of enzyme $0.6 \%$ to $1 \%$ is not significantly the change of restructuring parameters. This is result suitable with the statement of Yusro et al., (2011) in his research that the enzyme dosage of $0.6 \%$ is not significantly different with the dosage dosage of $1 \%$, But, the change of the parameters hardness, cohesiveness and springiness were significantly high with the dosage of $0,3 \%$ as well as meat control ( $0 \%$ enzyme dosage).

Tabel 3. Sampel Variations in Texture Profile Analysis on Animal Protein

\begin{tabular}{|c|c|c|c|}
\hline \multirow{2}{*}{$\begin{array}{c}\text { Enzyme } \\
\text { \% } \\
\text { dosage }\end{array}$} & \multicolumn{3}{|c|}{ Parameter } \\
\hline & $\begin{array}{c}\text { Hardness } \\
\text { (gf) }\end{array}$ & $\begin{array}{c}\text { Cohesiveness } \\
(-)\end{array}$ & $\begin{array}{c}\text { Springness } \\
(\%)\end{array}$ \\
\hline $0 \%$ & 99.80 & 0.553 & 67.25 \\
\hline $0,3 \%$ & 230.60 & 0.609 & 75.13 \\
\hline $0,6 \%$ & 263.30 & 0.662 & 79.81 \\
\hline $1 \%$ & 266.10 & 0.719 & 83.60 \\
\hline
\end{tabular}

\subsubsection{Vegetable Protein}

The result of Texture Profile Analyzer in vegetable protein can be seen on tabel 4 below.

Tabel 4. Sampel Variations in Texture Profile Analysis on Vegetable Protein

\begin{tabular}{|l|c|c|c|}
\hline \multirow{2}{*}{$\begin{array}{c}\text { Enzyme } \\
\% \\
\text { dosage }\end{array}$} & $\begin{array}{c}\text { Hardness } \\
\text { (Newton) }\end{array}$ & $\begin{array}{c}\text { Cohesiveness } \\
\mathbf{( - )}\end{array}$ & $\begin{array}{c}\text { Springness } \\
(\%)\end{array}$ \\
\cline { 2 - 4 } $0 \%$ & 40.756 & 0.123 & 20.753 \\
\hline $0,5 \%$ & 98.011 & 0.205 & 45.480 \\
\hline $1 \%$ & 119.621 & 0.215 & 58.967 \\
\hline $1,5 \%$ & 127.175 & 0.222 & 61.532 \\
\hline $2 \%$ & 132.161 & 0.207 & 60.452 \\
\hline
\end{tabular}

The table 4 above show that addition of transglutaminase enzyme effectively can increase the level of hardness up to $100 \%$, cohesiveness up to $90 \%$, and springness up to $100 \%$ in vegetable protein source. As for this research, the change of hardness value of vegetable protein only range from $40.756 \mathrm{~N}$ to 132.161 . Among the meat restructuring paramaters, the increasing hardness tends to be significant value as addition of dosage enzyme. However, on cohesiveness and springness parameters with the above $1.5 \%$ enzyme dosage, the their valued were tendency to decrease because the sample indicated to be too hard form and low elasticity..

\subsection{Proximate Test}

The proximate analysis is a set of methods to get information about the nutritional value of food. Chemical scheme of food analysis designed to measure only its basic five components namely, moisture, ash, fat, protein, and carbohydrate. the method used to measure moisture content and ash is Gravimetric Method, fat content is Hydrolysis - Soxhlet, protein content is Micro Kjeldahl, while carbohydrate content is by Difference. In this proximate test, the sample used in animal protein were compared the sampel contol which is TG $0 \%$ and $\mathrm{TG} 0,6 \%$, whereas the vegetable protein were compare the sampel control TG $0 \%$ and TG $2 \%$. Sampel $100 \mathrm{gr}$ is made for 5 basic test of proximate test. $100 \mathrm{gr}$ is for each animal protein and vegetable source.

\subsubsection{Animal Protein}

The result of Proximate analysis in animal protein can be seen on tabel below.

Tabel 5. Result in Proximate analysis of Animal Protein Source

\begin{tabular}{|l|c|c|}
\hline \multicolumn{1}{|c|}{ Parameter } & TG 0\% & TG 0,6\% \\
\hline Moisture (\%) & 73.63 & 72.32 \\
\hline Ash (\%) & 0.94 & 0.55 \\
\hline Fat (\%) & 4.77 & 4.81 \\
\hline Protein (\%) & 19.81 & 19.05 \\
\hline Carbohydrate (\%) & 0.85 & 3.27 \\
\hline
\end{tabular}

In the table above shows that the protein content slightly decreased. This happens because during the process of restructuring, duck meat is destroyed by way of chopped and blended first so that the occurrence of protein denaturation that causes the decline in protein values. Besides, prior to restructuring, meat is washed (leached) with water to clean up the dirt present in the meat so that many proteins are dissolved in water. This event is in accordance with the statement of Lanier and Lee (1982) [13], that during meat washing is separated from blood, pigment, fat, mucus and protein soluble in water. With the decline in protein content, the carbohydrate content is increased because it is calculated based on the difference. In the water content also 
increased. This can occur because at the time of washing process tends to increase the water content of meat due to the hydrophilic of meat.

\subsubsection{Vegetable Protein}

The result of Proximate Test in vegetable protein can be seen on tabel 6 belows.

Tabel 6. Result of Proximate analysis of Vegetable Protein (soy) Source

\begin{tabular}{|l|c|c|}
\hline \multicolumn{1}{|c|}{ Parameter } & TG 0\% & TG 2\% \\
\hline Moisture (\%) & 55.5 & 53.91 \\
\hline Ash (\%) & 2.68 & 2.83 \\
\hline Fat (\%) & 5.16 & 5.01 \\
\hline Protein (\%) & 24.35 & 23.44 \\
\hline Carbohydrate (\%) & 12.31 & 14.81 \\
\hline
\end{tabular}

The result in tabel above shows the addition of transglutaminase enzymes did not significantly alter the nutrients of the vegetable protein source product. However, in moisture test, the differences between before and after enzyme addition is quite significant. The cange from $55,5 \%$ untul $53,91 \%$ It is due to the coagulation process performed by transglutaminase enzyme reduces moisture level, so its affect to hardness, springness, cohesiveness. Then, a significant change is also on carbohydrate analysis. That is actually because of analysis method of carbohydrate is By Difference. In animal protein source, the results of proximate analysis has the same with vegetable protein, which is with the addition of transglutaminase enzyme did not affect significantly alter its nutrients.

\section{Conclusion}

The using of transglutaminase enzyme in animal and vegetable protein source affects the restructuring those proteins through crosslink reaction. The increase of $\mathrm{pH}$ level was due to the formation of ammonia $\left(\mathrm{NH}_{3}\right)$ from this reaction. The change of physical meat parameters due to restructuring showed that the hardness, cohesivenss and springiness (elasticity) were up to $100 \%$ for vegetable soy protein source and 300\% for animal protein source. The proximate analysis of meat restructuring, the addition of transglutaminase enzyme did not change significantly the nutrients in animal and vegetable protein source.

The authors would like to acknowledge the grant "Publikasi Internasional Terindeks untuk Tugas Akhir Mahasiswa" (PITTA) Universitas Indonesia with Grant number 2525/UN2.R3.1/HKP.05.00/ 2018 for the financial support during this research.

\section{References}

1. R. Huidobro, E. Miguel E, B. lázquez, E.A Onega comparison between two methods (Warner-
Bratzler and texture profile analysis) for testing either raw meat or cooked meat Journal of Meat Science pp 527-536 (20605)

2. M. Helena, M. Cambero, Ordonez J, L de la Hoz, Carmona P. Raman spectroscopy study of the structural effect of microbial transglutaminase on meat systems and its relationship with textural characteristics Food Chemistry pp 25-32 (2008)

3. B Min, Green B. Use of Microbial Transglutaminase and Nonmeat Proteins to Improve Functional Properties of Low $\mathrm{NaCl}$, Phosphate-Free Patties Made from Channel Catfish Belly Flap Meat Journal of Food Science 218-226 (2008)

4. Sarika K, Manjusha L, Mithlesh K, Nagalakshmi K, Venkateshwarlu G. Textural quality and oxidative stability of restructured pangasius mince: effect of protein substrates mediated by transglutaminase Journal Food Science and Technology (2013)

5. Marek Kieliszek \& Stanislaw Blazejak.. Microbial Transglutaminase and Applications in Food Industry. Faculty of Food Sciences, Department of Biotechnology, Microbiology and Food Evaluation. Warsaw University Of Life Sciences (2016)

6. Yun-Chu Wu. Development of Sectioned and Formed Meat Product using Deboned Meats. Departement of Animal Science Tunghai University. Tunghai University, Taichung, Taiwan, ROC. Access date: 26-12-2017.TV 9 (1): 61-71. (2002)

7. Mayashopha, A.Y., F. Herfianita \& A. Sutrisno. Application of Transglutaminase Enzyme on Food Product : A Review. Journal of Food and Agroindustri Vol.3 No 3 p.1145-1151 (2015)

8. Jiang S, Yin L Application of Transglutaminase in Seafood and Meat Processing Journal of Fish Science pp 151-162 (2001)

9. Motoki, M. \& Seguro, K. Transglutaminase and its use foor food processing. Trens in Food Science \& Technology (1998)

10. Winarno, F.G. Kimia pangan dan Gizi. Jakarta: Gramedia ((1993); (1995))

11. Yusro, N.F, Dewi, S.Z, A. Poernomo, K. Indra \& H. Nursyam. Karakterisasi dan aplikasi enzim transglutaminase dari streptoverticillium ladakanum pada daging lumat ikan mata goyang. Jurnal Pascapanen dan Bioteknologi Kelautan dan Perikanan Vol.6 No.2 (2011)

12. Zhuang-Li Kang, Xiang Li \& Han-Jun Ma. Effect of the levels of transglutaminase in frankfurters: a physical-chemical and Raman spectroscopy study, CyTA - Journal of Food, 15:1, 75-80 (2017)

13. Lanier, T.C and C. M. Lee. Surimi Technology. Marcel Dekker, New York. (1995)

14. Tellez-Luis, Simon J, Jose' A, Rocio M, Manuel V. Low-salt restructured fish products using microbial transglutaminase as binding agent Journal of The Science of Food and Agriculture 9 (2002)

15. Gonçalves, Alex A, Marcelo G. Restructured Fish Product from White Croacker (Micropogonias 
furnieri) Mince Using Microbial Transglutaminase Brazilian Archives of Biotechnology and Technology pp 987-995 (2010) 